\title{
The Long Shadow of History: Post-Soviet Border Disputes- The Case of Estonia, Latvia, and Russia
}

\section{Claes Levinsson*}

\section{Introduction}

Ever since the collapse of the Soviet Union in 1991, the question of the precise territorial delimitations of the Estonian and Latvian borders with the Russian Federation has been a source of discord between the states, and a permanent point of irritation. The question of these national boundaries became an important issue on the political agenda shortly after Estonia and Latvia regained their independence in 1991. The principal reason for this laid in the arbitrary transfers of territory and the "correction" of borders that was made by the Soviet government shortly after its reoccupation of the Baltic states. In 1991, both Estonia and Latvia pleaded their cases according to international law, and demanded that the borders from the interwar period should be restored. ${ }^{1}$ During the mid-1990s, both Estonia and Latvia gave up their initial claims, and the substance of an agreement was negotiated between the parties. However, the Russian Federation has ever since postponed the ratification of the agreement, claiming that it would not sign any treaty until other contested issues-such as the alleged discrimination against the large Russian-speaking minority in the Baltic states-are resolved in a satisfactory manner.

This means that there does not exist any formal and ratified solution to the question of the boundaries of Estonia and Latvia, and that the border issues between the parties are, at least formally, still unresolved. During the prolonged history of these border disputes, neither the EU nor NATO has actively interfered in the contretemps, and the absence of a ratified treaty did not prevent the accession of Estonia and Latvia to the EU and NATO in 2004.

By using the question of territorial delimitation and linking it to issues of domestic affairs in Estonia and Latvia, Russia is trying to impose its political will beyond its own borders. Furthermore, by keeping the territorial issue alive over alleged discrimination against ethnic Russians, Russia is demonstrating a lack of desire to improve bilateral relations with Estonia and Latvia, and is jeopardizing its relationship with the EU. The role of Russia as either a partner or a challenger in the Baltic region, and its willingness to form a strong future partnership with the EU, is first and foremost dependent upon how Russia will define its own position: through compromise or through geopolitical gamesmanship. But the stakes are also high for the Russian Federation, since it has expressed interests in achieving visa freedom for its citizens within the EU.

Claes Levinsson is a research fellow in peace and conflict studies in the Department of Eurasian Studies at Uppsala University.

1 Lithuania also made territorial claims against Russia. This dispute was solved in 1997, when a formal agreement was ratified by both Lithuania and the Russian Federation. 
To accomplish this, Russia needs to have its western borders officially recognized, and a precondition for this is resolving its border issues with Estonia and Latvia.

The background to these border disputes seems to follows a post-Soviet pattern, which attributes a great importance to a nation's territory and its territorial identity. As a contrast, in Western Europe there has been a trend to reduce the significance of national borders - for instance, through regimes like the Schengen Agreement-and to decrease the importance of the nation-state in general. In Eastern Europe, the trend during the past decade appears to have been the opposite. The collapse of the Communist state, and the resulting processes of state disintegration and state building that followed after the break-up of the Soviet Union, meant that the importance of territoriality in Eastern Europe increased and became a point of conflict, especially when the terrestrial spaces were linked to a territorial identity that implied a perceived historical continuity and national legitimacy. Estonia and Latvia followed this pattern up until the mid-1990s, when they renounced their nationalist territorial claims. The change in the position of Estonia and Latvia can, at least in part, be explained by the influence of the EU and NATO, since a major requirement for EU and NATO membership is that the applicant nation does not have any unresolved border issues with its neighbors. Nevertheless, up to the present, geopolitical considerations have been an important determinant in Russia's foreign and security policies. It has even been argued that an emphasis on geographic territory has dominated Russian security policy thinking for centuries. In the case of its western borders, this has often been expressed as a notion, deeply embedded in Russian historiography, of the Baltic rim as "old Russian land" and "our West."

However, the longstanding border disputes in the Baltic region are not only a manifestation of some post-Soviet condition. They are also testimony of some common characteristic between the function of borders and boundaries. In general, a state's borders are not only a divider between states, or a marker of the territorial unit that defines the state; they are also one of the foundational elements on which states define their security and their relations with other states. In this respect, borders can also function as a thermometer that can measure the degree of tension between states, and can be used to assess the significance of a particular security policy that defines the relationship between them. Wilson and Donnan stress this importance when they accurately describe borders as "the political membranes through which people, goods, wealth, and information must pass in order to be deemed acceptable or unacceptable by the state. Thus borders are agents of a state's security and sovereignty, and a physical record of a state's past and present relations with its neighbours."2

The political and social ramifications of borders became particularly relevant at the beginning of the twentieth century, when territory and the ideology of nationalism merged and created nation-states, which extended the value of territory from having a purely instrumental value in the thinking of the state to also include intersubjective symbolic values that touched on profound issues of identity. Territory became not only

2 T. Wilson and H. Donnan, eds., Border Identities: Nation and State at International Frontiers (Cambridge: Cambridge University Press, 1998), 9. 
a manifestation of state power, but also a perceived authentication of the state's inhabitants' past, present, and future. It thus created a territorial identity that objectified a perception of an ethnic, racial, linguistic, and cultural homogeneity among the inhabitants of the state. However, the problem is that, more often than not, state borders do not coincide with the boundaries of ethnic groups. Rather, this vision of the nationstate is an ideal image of the world that emerges from a nationalist conception. The borders that nationalists many times see as "sacred" and "eternal" are for the most part a creation of the state, not the nation. ${ }^{3}$ It is a perception that very often creates tensions not only within states but also among states. This is something that can be viewed as a "tug of war" between spatiality and temporality.

In a general perspective, one may observe that, in Eastern Europe, the temporal horizon currently seems to be predominant over the spatial one-i.e., the way in which terrestrial space is thought of as affecting the organization of given phenomena, such as power or social relations. ${ }^{4}$ The new territorial configurations that emerged in the wake of the Cold War and the subsequent process of state building have often been based on a traditional, sedentary, and pre-national notion of territory and society. The spatial horizon is limited, whereas the temporal horizon, defined by history and myth, extends back to a distant past and is often perceived as eternal. ${ }^{5}$ The spatial horizon is often expressed by different efforts of integration in a regional or international context. When the spatial horizon meets the temporal, it often creates tensions and sometimes even new battle lines, both within and between these new states. Pierre Hassner speaks of the pathology of territories that are "torn between centrifugal and centripetal forces, between diversity and homogeneity, between union and separation-all impossible to carry to their ultimate consequences. Hence the dialectic of the problems of minorities, frontiers, and migrations." 6 This kind of territorial pathology seems to have been a distinguishing quality of the developments in the territory of the former Soviet Union ever since the end of the Cold War. Indeed, the post-Soviet record of territorial disputes is extensive. By late 1991, there had been some 170 ethno-territorial disputes in the former USSR, 73 of which directly concerned Russia. Furthermore, there were only two out of twenty-three inter-republic borders within the former Soviet territory that were not in dispute. ${ }^{7}$ Many of these conflicts have continued to plague Russia ever since. The Estonian and Latvian border disputes with Russia are in this respect no exception.

3 R. Brown, "Globalization and the End of the National Project," in Boundaries in Question. New Directions in International Relations, eds. J. Macmillan and A. Linklater (London: Pinter, 1995), 57. J. Agnew, Geopolitics: Re-visioning World Politics (New York: Routledge, 1998), 129.

5 Pierre Hassner, "Obstinate and Obsolete: Non-Territorial Transnational Forces versus the European Territorial State," in Geopolitics in Post-Wall Europe: Security, Territory and Identity, eds. O. Tunander, P. Baev, and V. Einagel (London: Sage Publications, 1997), 54. Hassner, "Obstinate and Obsolete," 56.

7 P. Baev, "Old and New Border Problems in Russia's Security Policy," in Contested Territory. Border Disputes at the Edge of the Former Soviet Empire, ed. T. Forsberg (Cheltenham: Edgar Elgar, 1995), 92. 


\section{History}

The border dispute between Estonia and Russia has revolved around the area of Jaanilinn/Ivangorod on the eastern bank of the Narva River, and the areas surrounding Petseri/Petchory south of Lake Peipus. In total, the areas make up about 2500 square kilometers, and constitute the whole of Estonia's eastern border. In connection with the re-establishment of independence, the Estonian Republic claimed these areas because of its previous ownership of them during the interwar period. During the Soviet period, both areas were involuntarily transferred and incorporated into the Russian Soviet Federated Socialist Republic (RSFSR).

The legal basis for Estonia's possession of both areas goes back to 1920, when Russia concluded a peace treaty that enabled Estonia's first political formation to be recognized, not only de facto but also de jure. In the peace treaty, which was ratified in Tartu in February 1920, the territory of Estonia was defined, and its borders were demarcated. In the same treaty, Russia promised "for ever and for good" to recognize and respect Estonia's independence and territorial integrity. ${ }^{8}$ The legitimate foundation for Estonia's territorial delimitation was cited as being support among the local population in the areas. In Petserimaa, this was manifested in the form of a petition submitted to the National Council of Estonia; in Narva, a referendum had been held on the question of uniting the territory with Estonia. 80 percent of the inhabitants in the area were in favor of unification. ${ }^{9}$

Shortly after its reoccupation of Estonia, the Soviet government began to make "border adjustments," and transferred the trans-Narva part of the Viru District and most of the Petseri District to the Oblasts of Leningrad and Pskov, to become component parts of the Russian SFSR. In January 1947, the transfer was formally adjusted by the Supreme Soviet of the Russian SFSR. All in all, the transfer of both areas amounted to some 5 percent of Estonia's pre-war territory, containing approximately 6 percent of its total population. ${ }^{10}$

In Latvia, the border change took place in the northeastern Abrene district. The legal grounds for Latvia's former possession of the area were similar to Estonia's. In 1920, Latvia concluded a peace treaty with Russia that stipulated Latvia's sovereignty and territorial integrity. In the peace treaty, ratified in Riga in August 1920, Soviet Russia undertook the obligation to recognize Latvia's independence and "for ever, relinquish ... all former Russian supreme rights over Latvia and its people." "11

After its reoccupation of the Baltic states, the Soviet Union "corrected" the border between Latvia and Russia, and incorporated the city of Abrene (formerly Jaunlatgale) together with six rural districts in the Abrene area-Kacenu, Upmales, Linavas,

8 M. Graham, The Diplomatic Recognition of the Border States (Berkeley: University of California Press, 1940).

9 I. Jääts, “East of Narva and Petserimaa," in Contested Territory, ed. Forsberg, 190.

${ }^{10}$ E. Anderson, "How Narva, Petseri and Abrene Came to Be in the RSFSR," in Regional Identity Under Soviet Rule: The Case of the Baltic States, eds. D. Loeber, L. Kitching, and V. Vardys (Kiel: University of Kiel, 1990), 403.

11 Ibid., 403, note 8. 
Purvmalas, Ugspils, and Gauru-into the Russian SFSR. The territory was in many ways insignificant, with a predominantly rural population and no larger industries. The principal reason for the Soviet interest in this territory was most likely Abrene's close connection to the Estonian Petseri district, and the role the area played in Estonia and Latvia's contingency plans for the initial defense of these countries in the event of a Soviet invasion. The area was transferred to the Russian SFSR through a governmental decree issued by the presidium of the Supreme Soviet of the Latvian SSR in August 1944. The reason for this transfer was the alleged wish of the inhabitants of Augspils, Kaceni, and Linava to have their communities attached to the Russian SFSR. ${ }^{12}$ However, it is interesting to note that the transfer was performed in obvious violation of the Soviet Union's own constitution, since only fifty-two out of one hundred deputies took part in the deliberation, and a plebiscite was not held in the affected areas. Furthermore, as Daukts and Puga have pointed out, most of the inhabitants in the region in question did not find out about the decision until a long time after August $1944 .{ }^{13}$ Shortly after the transfer, Abrene was given its Russian name of Pytalovo.

The transfer was finally settled in January 1947, when the Supreme Soviet of the Russian SFSR by decree formally took over the district of Abrene. In 1938, the ethnic composition of the district of Abrene was 55 percent Latvian, 41.7 percent Russian, and 3.3 percent others. In 1945, the corresponding figures in the area were 85.5 percent Russian, 12.5 percent Latvian, and 2 percent others. The territorial losses accounted to some 2 percent of Latvia's pre-war area. ${ }^{14}$

One immediate result of the Soviet occupation was the abolishing of all international borders between the republics of the Soviet Union. Instead, the Soviet government replaced them with what it called "administrative lines." These lines were never demarcated, and did not have any practical political, economic, or geographical significance. In theory, the republics were granted status as autonomous entities, with their own constitutions, supreme courts, governmental organs, and a right to secede from the federation. The theory, however, did not stand up to the fact that the Soviet Union's republics were neither equal nor autonomous, and did not have any practical possibility to secede from the federation. In fact, despite the frequency of internationalist usage in communist ideology, and its sharp dissociation from the former tsarist empire, the Soviet Union's official political rhetoric was not lacking in historical references to previous Russian possessions in the Baltic region. In its efforts to legitimize its pretensions and occupation, the Soviet Union emphasized the idea and myth of the Baltic rim as a time-honored Russian land, with historical ties that went back to the Middle Ages. This was also reflected in the bogus guarantees of political and cultural independence that were made to the Soviet republics. In reality, all power was concentrated in Moscow, Russian personnel in the Baltic region held all the important posts, and the Communist Party controlled every aspect of the political, economic, social, and cultural life in the Baltic republics. The Baltic states not only suffered from territorial

12 Ibid., 404, note 10.

13 B. Dauksts and A. Puga, “Abrene,” in Contested Territory, ed. Forsberg, 178.

14 Ibid. 
losses and a repressive transformation of their society; they also suffered from dramatic shifts in their demography.

The ethnic composition of the population in the disputed areas changed during the post-war period. This shift in the region's demography was above all a result of deportations and labor allocation. By the middle of the 1980s, the ethnic composition had changed in the disputed areas to such an extent that a majority of the native population had either voluntarily or by force left the districts. However, this demographic shift did not only occur in the borderlands, but particularly in Estonia and Latvia proper as well. The large immigration of mainly Russians, and other individuals with Russian as their mother tongue, started immediately after World War II ended in 1945, when demobilized soldiers and civil servants where given work in the region. Since the war had taken an enormous toll of human lives, all of the Soviet Union suffered from a structural shortage of labor and a reduced population. In Estonia, the population had fallen from 1.13 million in 1939 to some 850,000 in 1945. The trend of Russian settlement in Estonia meant that the total population rose dramatically within a few years, and amounted to 1.19 million in 1959. The percentage of ethnic Russians and Russian speakers rose during these few years from 8.2 percent during the interwar period to 20 percent of the total population in 1959. From 1959 to 1989, the percentage of the Russian-speaking population continued to rise, to 30.3. A similar development occurred in Latvia, where the Russian-speaking portion of the population rose from 10.6 percent during the interwar period to 26.6 percent of the total population in 1959. In 1989, the ethnic Russian population amounted to 34 percent of the total population. ${ }^{15}$

\section{The Dispute}

The basis of Estonia and Latvia's territorial identity was the particular state formation that existed during the interwar period, combined with a period of actual historical possession of the territory. The 1920 peace treaties from Tartu and Riga represented the main foundation for the states' existence as nation-states, and constituted the primary basis for the restoration of statehood. This was also something that was clearly stated in their respective constitutions. Thus their claim to the disputed areas was considered to have both international legality and historical justification. ${ }^{16}$

Russia, on the other hand, based its arguments on present circumstances, and claimed that the majority of the inhabitants in the disputed areas were Russian, despite the fact that these circumstances had been created as a result of Soviet resettlement policies. Another reason for Russia's position, and probably a more important one, was the question of precedents. As mentioned above, at the beginning of 1991 some 170 ethno-territorial disputes were active in the former Soviet area, of which 73 directly involved borders of the Russian mainland. This was further complicated by the fact that nearly a quarter of Russia's 61,000 kilometers of border was not formally recognized

15 A. Lieven, The Baltic Revolution: Estonia, Latvia, Lithuania, and the Path to Independence (New Haven: Yale University Press, 1993), 183; Eesti Stastistika, Tallin, 1997.

16

See, for example, Forced Migration Project, Estonia and Latvia: Citizenship, Language and Conflict Prevention (New York: Open Society Institute, 1997), 18. 
and specified in any international treaties. ${ }^{17}$ To give up a strip of land on one portion of the border could therefore backfire in other regions. The Baltic-Russian border could therefore be the first brick to fall in the Russian territorial domino game. Hence, for Russia it was crucial to dismiss all claims on its borders, and under no circumstances to negotiate a compromise in its ongoing disputes.

The boundary disputes between Russia and Estonia were first formally articulated in July 1992, when the Estonian government issued a statement calling on Russia to withdraw her border guards back to the boundary established in the Tartu peace treaty of $1920{ }^{18}$ The Russians issued a strong response, with the Russian foreign ministry sending a note accusing Estonia of making unjustified territorial claims on Russia and threatening Estonia with economic sanctions. Russia did, however, agree to engage in talks with its Estonian counterpart. ${ }^{19}$ Nevertheless, one year of bilateral talks did not produce any solution to the dispute, and the conflict became aggravated when Russiawithout Estonia's consent-decided to fix the Soviet borderline as the official state border of Russia. Estonia viewed this move as the equivalent to Russia having laid territorial claim to Estonian soil. ${ }^{20}$

In February 1994, Russia stated that it might demarcate the borderline unilaterally if no progress was made in the talks. The Estonian reply was that, once Russia recognized the Tartu peace treaty, the border talks would become more flexible and forwardlooking in nature. At the time, the level of international support for the Estonian claims was weak, above all because most international interest was directed towards the withdrawal of Russian troops from Baltic soil. That meant that Russia could take full advantage of the asymmetric power relationship that existed between the parties. Consequently, Estonian complaints and proposals that the matter should be settled at the International Court of Justice in The Hague fell on deaf ears. ${ }^{21}$

Another round of border talks was initiated in late November of 1995, and a consensus regarding the maritime border was reached. However, the key stumbling block was still the terrestrial border. Ever since the beginning of the dispute, the Russian side

17 Ibid., 18, note 5.

18 RFE/RL, Supplement 1:31 (1992): 72.

19 Ibid., 72, note 9.

20 The Baltic Independent, 26 February 1993. As the negotiations reached a deadlock, some incidents on the border occurred. In May 1993, approximately 2000 Estonian cyclists approached the border demanding to be allowed into the town of Petseri. The group arrived without visas and passports, and was stopped by Russian border troops. The cyclists then staged a protest under the slogan "Petseri is Estonian land. Occupiers, clear out of the Petseri district." More fuel was added to the fire when Russia began to erect new permanent checkpoints at the border, and when Russia officially decided to renounce the 1920 peace treaty. This was in practice perceived as a de facto statement of non-recognition of the Estonian state. See ITAR-TASS, 15 May 1993; The Baltic Independent, 16 June 1993.

${ }^{21}$ In addition, when the Russian president Boris Yeltsin visited the border in November 1995, he vowed that Moscow would not give up "one single centimeter of land no matter who claims it." The Baltic-Russian borders, he stated, were used by foreign intelligence to "penetrate the territory of Russia.” Reuters, 23 November 1995. 
tried to link every round of bilateral border talks to the situation of the Russian-speaking minority, accusing the Estonian authorities of systematically discriminating against this population. This issue was further linked to the question of the removal of Russian forces from Estonia. This introduction of multiple issues into the boundary negotiations complicated all efforts to reach some sort of solution. After a meeting in Pärnu in March 1996, Estonia and Russia succeeded in drawing up a "comprehensive" draft agreement on the delimitation of their common border. ${ }^{22}$ The draft was focused solely on technical issues, however, and the overall deadlock continued, since Estonia refused to compromise on the principles outlined in the Tartu peace treaty regarding Estonian sovereignty.

Shortly before a second meeting in Petrozavodsk in November 1996, however, Estonia dropped all references to the Tartu treaty. The change of Estonia's position meant that Estonian and Russian negotiators could agree on a so-called technical border agreement, without reference to other treaties. In Petrozavodsk, Estonia insisted on a formal ratification of the agreement but Russia, as usual, put forward the question of the Russian-speaking minority, and claimed that the treaty was technically not ready for signing. ${ }^{23}$ This meant that a resolution was once again blocked by Russia's concern over so-called humanitarian principles, and that the border issue again was sent back to the expert level.

In Latvia, the border dispute did not reach the same level of significance in domestic politics as it did in Estonia. One reason could be that the pullout of the Russian troops was more complicated in Latvia than in other parts of the Baltic region. Still, this does not mean that the restoration of Latvia's pre-war borders was considered an insignificant issue. In February 1992, the Latvian Supreme Council adopted a resolution "on the non-recognition of the annexation of the town Abrene and its six oblasts." With this decree Latvia confirmed its adherence to the borders established under the 1920 Riga peace treaty with Russia. Russia's response came a month later, when they officially rejected the Latvian resolution. The Russian government stated that the Latvian claims were "absolutely groundless, both historically and from a juridical point of view."24

The first steps towards the normalization of relations were taken in 1993 when an agreement was signed regulating cross-border movements. Shortly after the agreement was ratified, both parties began, in silence, to demarcate the non-disputed part of the boundary. After the Russian troop withdrawal, there was another opening in the border talks when the then foreign minister of Latvia, Valdis Birkavs, advocated a rapprochement between the states. His proposal was that the boundary issue should be dealt with by introducing a temporary borderline until a permanent solution could be reached. ${ }^{25}$ Arriving at a solution based on both parties' consent, however, was complicated, since

22 BNS, 29 February 1996.

23 ITAR-TASS, 5 November 1996.

24 SWB SU/1286.1328 (1992).

25 D. Bungs, Seeking Solution to Baltic-Russian Border Issues, RFE/RL Research Report 3:13 (1 April 1994), 25 ff. 
Russia introduced the question of the Russian-speaking minority and their status in Latvia into the border talks. The Latvian refusal to eliminate any reference to the Riga peace treaty was another snag in the negotiations.

However, at the beginning of 1997 the Latvian government consulted its parliament and proposed a coordination of its policy with Estonia on the question of the states' borders with Russia. In effect, this meant that Latvia also dropped its dogged attachment to the Riga peace treaty in its border talks with Russia. ${ }^{26}$ In February, after an allnight session of talks, delegations from Latvia and Russia agreed upon the basic provisions of a draft treaty on their shared border. The formal ratification of the agreement was delayed, however, after Russia insisted on amendments. Later, on 31 March, Latvia made its position clear when Latvian President Ulmanis stated that, "while Latvia strives to reach an agreement, the signing of such should not be linked to humanitarian issues," i.e., the status of Latvia's Russian-speaking minority. The Russian standpoint was further concretized when the Russian State Duma in May issued a warning that, if Latvia did not end the discrimination against the Russian-speaking minority, not only would the Duma not ratify any border agreement, it would also impose economic sanctions. ${ }^{27}$

Estonia and Latvia's decisions to disconnect the question of the validity of the Tartu and Riga peace treaties from the negotiations of their national borders meant that all the disputed areas were ceded to Russia. The finalization of Estonia's cession took place in Moscow in August 1998 at a meeting between the heads of the border delegations, and at a meeting in St. Petersburg in March 1999 between Estonia's and Russia's foreign ministers. The latter meeting was of a practical nature, to confirm the technical agreement that had been negotiated earlier in which the principles for a demarcation of the land border were agreed upon. This meant that all formal negotiations between Estonia and Russia about their common boundary were over. The next step in the process was to submit the issue for formal ratification by the parliaments of both states, which would then allow for a definitive demarcation of the boundary. ${ }^{28}$ Even though a treaty was finalized, the ratification was postponed by the Russian Federation, which claimed that it would not sign any border treaties until other contested political issues were resolved in a satisfactory manner.

\section{The Present Situation}

The question of the borders between Estonia and Latvia and Russia again became the subject of active discussion after the Baltic states' accession to EU membership in May 2004. According to the charter of this organization, member countries should not have territorial disputes with neighboring states. But the absence of a border treaty did not prevent the introduction of the Baltic states to the organization, since both Estonia and

26 SWB SU/2765, 1997.

27 ITAR-TASS, 14 April 1997; RFE/RL, 7 May 1997.

28 Estonian Foreign Ministry, Information Sheet, 29 March 1999. 
Latvia could claim that they had been ready to sign the treaties since they were initialed in 1999.

On 18 May 2004, after renewed negotiations, the Russian Minister of Foreign Affairs Sergey Lavrov and his Estonian counterpart Urmas Paet signed the long-awaited border agreement in Moscow. On 27 June, merely six weeks after signing the treaty, Russia announced that it had revoked its signature, withdrawing from any obligations stipulated in the treaty, and demanded a renegotiation from scratch. ${ }^{29}$

As had been the case after the previous round of negotiations, the ratification of the agreement stirred up the long-standing question of Estonia's historical legitimacy, and whether or not the Soviet Union "liberated" or "occupied" the Baltic states shortly after World War II. In the Estonian ratification preamble, Estonia made a non-binding reference to the state's legal continuity during the Soviet occupation-from the peace agreement in Tartu in 1920 up to the present. Apart from the preamble, the Russian withdrawal was also a slap in the face of the European Union. According to Lavrov, Russia's Minister of Foreign Affairs, “They in the EU might have succumbed to the temptation of telling us, well, Estonia has ratified it, even if adding references to 'occupation,' 'aggression,' 'unlawful annexation,' but ratified it anyway ... so please show a bit of patience and ratify it on your side, also with some interpretations attached, so that the treaty can enter into force. To stop the EU from falling into this temptation, we have withdrawn our signature. There will be no treaty." 30 The Duma's International Affairs Committee Chairman, Konstantin Kosachev, emphasized the government's position by stating that "Estonia just did not want to behave in a civilized manner."31 Even though the Estonian government wants the border issue resolved, it simply cannot sanction the Russian position, since an agreement without a preamble acknowledging the state's legal continuity creates the impression that Estonia as an independent state arose only in 1991.

The question of Latvia's border agreement with Russia followed a similar path. The only difference is that the opposition to a border agreement is much stronger in Latvia. The Latvians insisted on a unilateral declaration in the agreement that stated Latvia's historical rights over the Abrene district. This provoked a harsh reaction from Moscow, and the signing of the agreement that was scheduled for 10 May 2005 was postponed indefinitely. ${ }^{32}$ Latvia argued that it was not advancing any territorial claims with this statement, but was just offering an explanation of its history and the effects of the Soviet occupation. The Latvian Prime Minister Aigar Kalvitis regarded the Russian

29 Interfax News Agency, 27 June 2005.

30 Interfax News Agency, RIA, 27-28 June 2005. The order for Russia’s withdrawal was signed by President Putin on 1 September.

31 RIA-Novosti, 27 June 2005.

32 President Putin warned that, if Latvia pressed any territorial demands, it would get not land but "dead donkeys' ears." He further accused the Latvian government of "political demagoguery," and said making territorial claims while simultaneously seeking a border treaty was “complete nonsense and rubbish.” At www.Pravda.Ru, 23 May 2005. 
protest as "very sharp," and concluded that, "If such a sharp reaction continues, constructive talks will certainly be complicated., 33

The ratification of the border agreements was further complicated by a meeting in Pärnu, Estonia, in April 2005, at which an assembly of representatives of the Baltic states called upon Russia to acknowledge the fact of the Soviet Union's occupation of the region in 1945. The Baltic states were supported by the U.S. Congress, which passed a resolution on 21 May 2005 stating that the government of Russia should recognize and unambiguously condemn the Soviet Union's illegal occupation and annexation of the Baltic states—Estonia, Latvia, and Lithuania-from 1940 to 1991.

For Estonia and Latvia, the border issue, with its linkages to historical legitimacy and cross-border minorities, has in many ways been an emotional question that hinges on the legality of the inter-war state and the subsequent Soviet occupation. Both Estonia and Latvia based their attitude in the border disputes on the legality of the 1920 peace treaties of Tartu and Riga, which established the states' internationally-recognized borders. The following alterations of these borders during the Soviet period are regarded to have no legal or political legitimacy. Instead, both states are advocating a principle, or notion, of state continuity, wherein the contemporary government is seen as a continuation of the inter-war governments. The practical meaning of this is that the government of the territories during the Soviet era was illegal, and lacks any political or legal significance for the contemporary state. The consequence of this is that all Russians who moved into the area during the Soviet period did and do not automatically enjoy the right of citizenship. This also means that the transfer of the disputed areas was considered illegal.

On the other hand, ever since its independence, Russia has been maintaining that the Soviet Union neither annexed nor occupied the Baltic states. Instead, the Soviet Russian presence in the Baltic littoral was the result of interstate treaties. As a consequence, Russia did not recognize the Baltic states' legal continuity and restoration of the inter-war state. Russia viewed the Baltic states' declarations of independence in 1991 as a result of the break-up of the Soviet Union, and considered them to be three entirely new states, with no legal connection to the nation-states of the inter-war period. The effect of the Russian logic is that, since the incorporation of the Baltic states into the Soviet Union was conducted in a legal and rightful fashion, by treaties between independent states, the border "corrections" that took place shortly after World War II are also legal. ${ }^{34}$

The Russian position has been unchanged since the border negotiations stalled in 2005. In June 2006, Sergei Lavrov said Russia would only rejoin negotiations if the Baltic states returned to the original documents and removed the political subtexts: "But as long as these political links are there, returning to the negotiating table is out of the question." 35

33 RIA-Novosti, 11 May 2005.

34 Reuters, 27 January 1994; S. Chernichenko, “Ethnic Russians in the Baltics,” International Affairs (1998).

35 RIA-Novosti, 7 June 2006. 


\section{Conclusion}

By using its position as a regional hegemon, Russia has tried to interfere in Estonia and Latvia's domestic affairs by tying the border issue to the question of the states' historical legitimacy and alleged discrimination against cross-border minorities. The Russian refusal to come to terms with the boundary question is in part due to domestic policy considerations, and in part to geopolitical strategies. Russian domestic policy is shaped and executed in a highly nationalistic and chauvinistic political environment, chiefly represented by the Russian State Duma, where many of the deputies stand for a policy towards the Baltic states based on force and power rather than compromise and cooperation.

Both sides have used-and in some cases even abused-history in the political dialogue, and have tried to exploit the issue of cross-border minorities in order to point out the historical continuity of the territory and its borders. On both sides there has been an attempt to construct a territorial identity, in which the territory and its borders function as a principal symbol for independence and a physical record of the state's past, present, and future. Despite this, there does exist a climate for dialogue instead of confrontation in the region. However, as far as the question of the borders is concerned, the ball is now in Russia's court. Russia can choose to further exploit the present situation, or to move in a more progressive direction. This climate means that Russia has to choose cooperation, and to accept that the Baltic states are outside Russia's sphere of influence.

Even if there are no ratified agreements bearing the imprimatur international legality between the Baltic states and Russia on this issue, there is hardly any reason for an escalation of the border disputes. As far as Estonia and Latvia are concerned, the absence of a treaty is an irritant, but not a major problem. During the course of the border dispute, both Estonia and Latvia have changed their initial positions and gradually reformulated their early demands. This was evident in the most recent round of negotiations, when both Estonia and Latvia searched for a solution to find a middle ground, and displayed their willingness to back down from the initial references to their prewar boundaries. Nevertheless, the snag continues to be the Baltic states' insistence on making reference to the historical legitimacy of their territory and sovereignty. But a formal solution to the disputes is probably dependent on which domestic and geopolitical considerations Russia ultimately favors. A probable scenario is that Russia eventually will ratify the agreements simply because Russia needs a stable border regime with the Baltic states.

Another scenario is that Russia will maintain the present situation by using the border agreements, the question of the historical legitimacy of the Baltic states, and the status of the Russian-speaking minority as a pretext for preserving the status quo in the region. Up to the present, this strategy has dominated Russia's policies towards Estonia and Latvia. However, it seems unlikely that Russia will pursue that strategy in the near future. This shift is not due to a sudden change in the Russian perception of the Baltic rim as a part of its zone of interest, but because of other interests that appear to have a higher priority—not least manifested by Moscow's desire to participate in the political and economic framework of the region. 


\section{Bibliography}

Agnew, J.. Geopolitics: Re-visioning World Politics. New York: Routledge, 1998.

Baev, P.. "Old and New Border Problems in Russia's Security Policy." In Contested Territory. Border Disputes at the Edge of the Former Soviet Empire. Cheltenham: Edgar Elgar, 1995.

Brown, R.. "Globalization and the End of the National Project." In Boundaries in Question. New Directions in International Relations., 1995.

Graham, M.. The Diplomatic Recognition of the Border States. Berkeley: University of California Press, 1940.

Hassner, Pierre. "Obstinate and Obsolete: Non-Territorial Transnational Forces versus the European Territorial State." In Geopolitics in Post-Wall Europe: Security, Territory and Identity. London: Sage Publication, 1997.

Lieven, A.. The Baltic Revolution: Estonia, Latvia, Lithuania, and the Path to Independence . New Haven: Yale University Press, 1993.

Wilson, Thomas M., and Hastings Donnan. Nation and State at International Frontiers. Cambridge: Cambridge University Press, 1998. 